\title{
10
}

\section{United Arab Emirates}

United Arab Emirates (UAE) is a Middle Eastern federation comprising seven states Abu Dhabi, Ajman, Dubai, Fujairah, Ras-al-Khaimah, Sharjah and Umm-al-Quwain. Abu Dhabi, Dubai and Sharjah are the three largest states in terms of population as well as the size of their economies. UAE is an oil rich country, with 9 per cent of total world reserves of crude oil and 5 per cent of world reserves of natural gas. In 2004, it had a real per capita GDP (PPP-adjusted) of US $\$ 22,000$ and a population of 4.3 million. With an average annual growth rate of over 7 per cent since 2000, the UAE economy is one of the fastest growing in the world.

The importance of trade of goods and services to the country is substantial, and trade constituted 145 per cent of GDP in 2004. The country maintains a trade surplus, primarily because of its large oil and gas exports. Foreign direct investment (FDI) inflows to UAE increased rapidly in the last few years (Chart 10.2). They stood at US $\$ 10$ billion in 2004 and inched up to US $\$ 12$ billion in 2005 (UNCTAD, 2005).

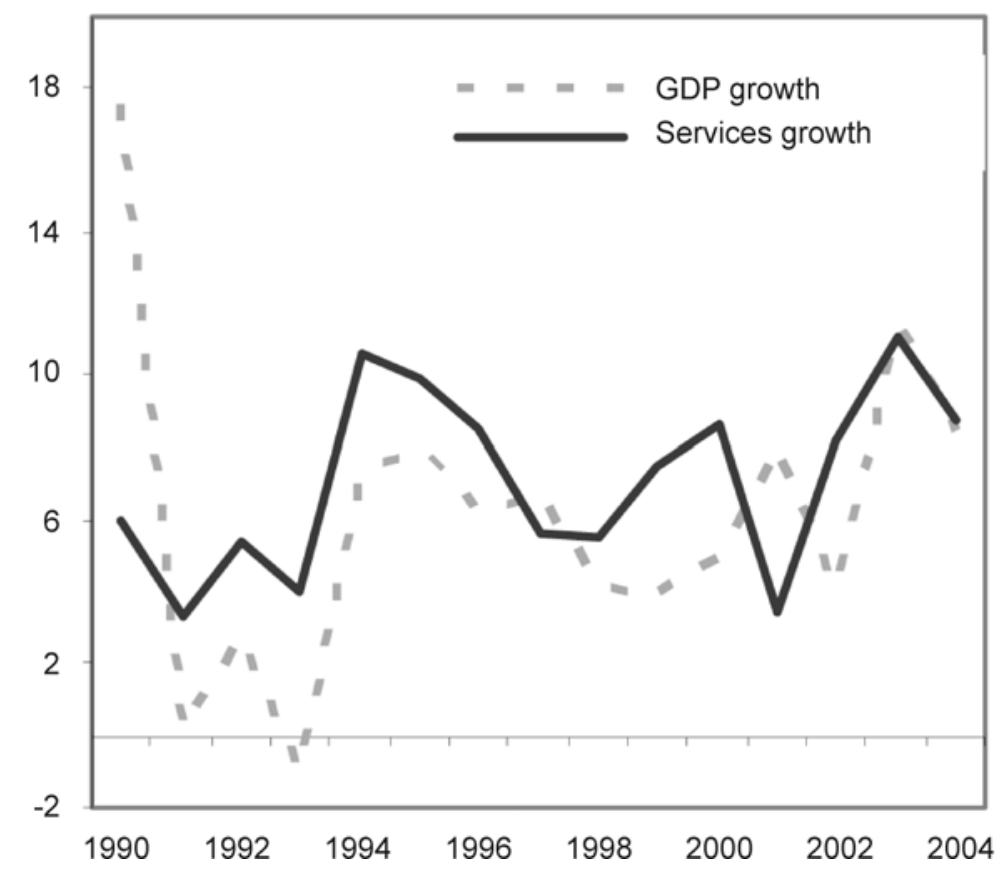

Chart 10.1: Annual GDP and services growth rates for UAE (\%)

Source: World Bank (2006) 
The leading sectors for FDI are oil- and gas-field machinery and services, power and water, computers, medical equipment and supplies, airport development and ground equipment, telecommunications and franchising.

Although the importance of manufacturing has increased since the late-1990s, the services sector continues to be the main contributor to the economy with shares of over 40 and 50 per cent in GDP and total employment respectively (Chart 10.3). Since 1990, the services sector has recorded impressive growth and has expanded at an average rate of more than 7 per cent. The main services sub-sectors contributing to GDP are trade (external trade [transshipment and re-export]), wholesale and retail trade, real estate and construction activities, and transport storage communications; these sub-sectors had a combined share of 35 per cent of GDP in 2004.

\section{Performance of services}

The share of the financial services sector in GDP was about 6 per cent in 2004. The sector grew at an average rate of 8 per cent during 1999-2004 (Table 10.1). In the financial and insurance services sector in 2004, there were 46 commercial banks (21 national and 25 foreign), 50 representative offices of foreign banks, two investment banks, seven financial investment companies, seven finance companies, 12 financial consultancies and 46 insurance companies (50 per cent local). The country's banking sector is in general efficient, competitive and profitable.

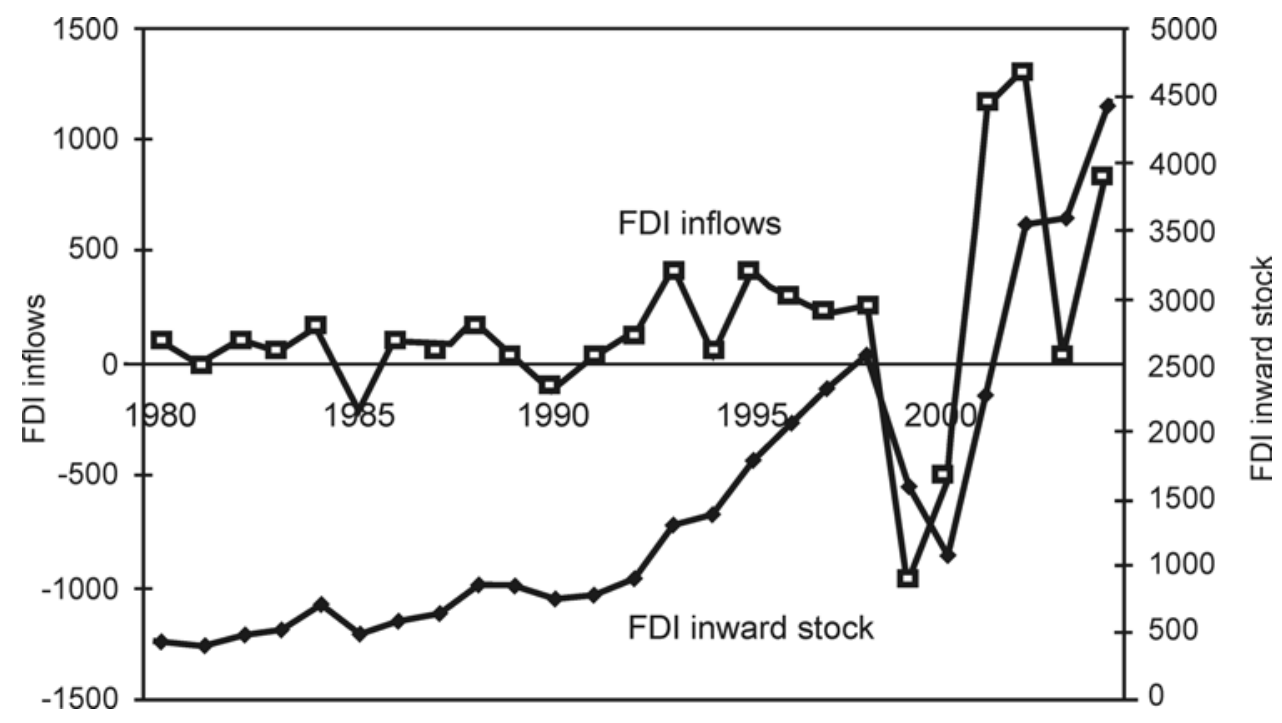

Chart 10.2: FDI inflow and FDI inward stock for UAE (US\$ million)

Source: UNCTAD (2005) 


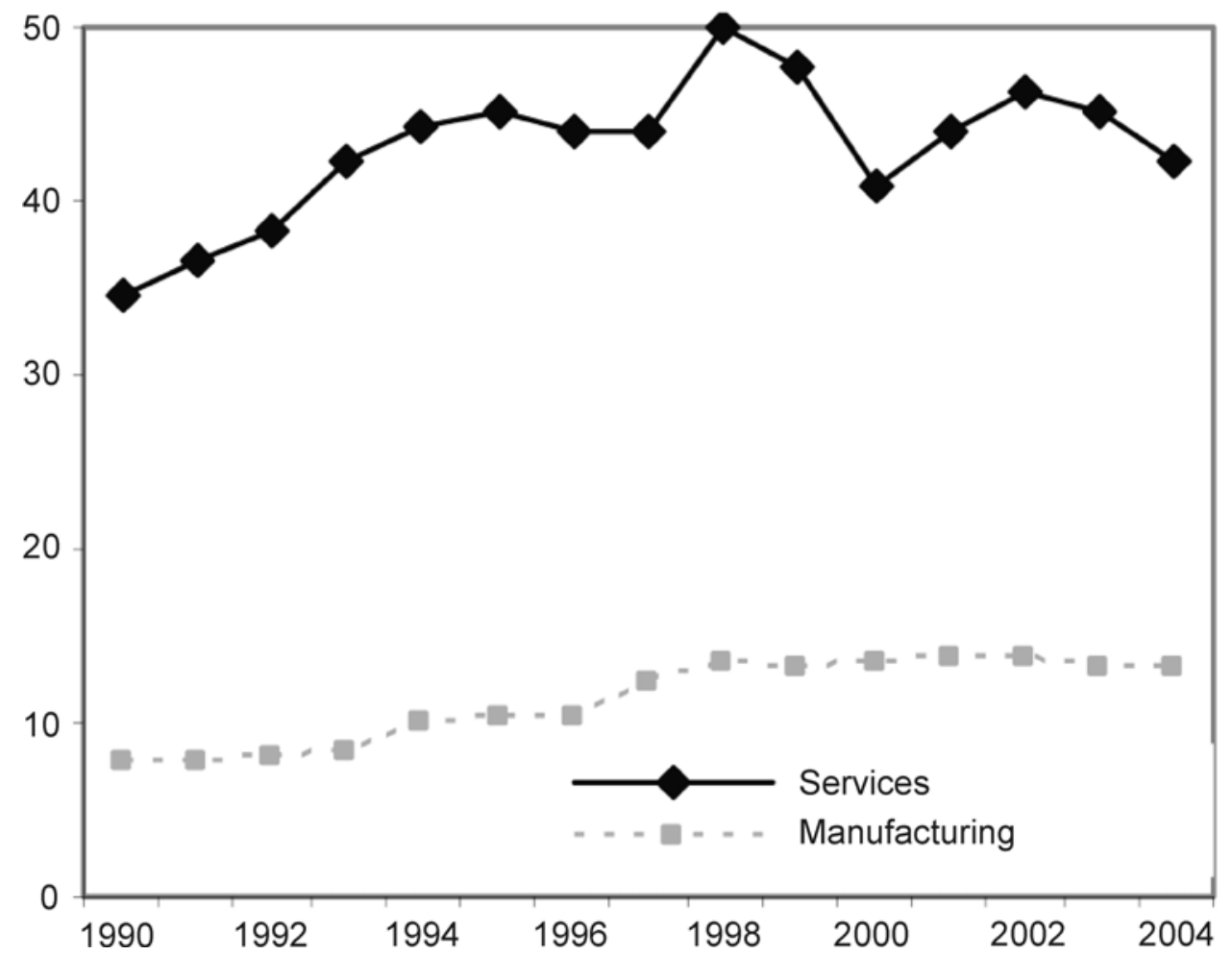

Chart 10.3: Share of manufacturing and services in GDP for UAE (\%) Source: World Bank (2006)

Real estate services accounted for 10.0 per cent of GDP in 1995, but this share decreased to 7.8 per cent in 2004. On average, the sector has been growing at a slower rate as compared to other services (see Table 10.1).

Table 10.1: Growth in real terms for selected services (\%)

\begin{tabular}{lccccccc}
\hline & 1999 & 2000 & 2001 & 2002 & 2003 & 2004 & $\begin{array}{c}\text { Average } \\
\text { (1999-2004) }\end{array}$ \\
\hline Trade, restaurants \& hotels & 4.0 & 3.4 & 1.2 & 17.3 & 17.3 & 6.2 & 8.2 \\
Transport \& communications & 9.9 & 14.3 & 6.1 & 7.1 & 7.8 & 10.1 & 9.2 \\
Finance \& insurance & 5.2 & 7.6 & 12.1 & 0.9 & 8.1 & 15.9 & 8.3 \\
Real estate & 3.8 & 0.9 & 1.6 & 11.2 & 8.1 & 14.1 & 6.6 \\
Other services & 6.0 & 7.2 & 7.0 & 22.7 & 9.9 & 4.8 & 9.6 \\
\hline
\end{tabular}

Source: WTO (2006) 
The share of transport, storage and communications in GDP increased from 6.7 to 7.2 per cent from 1995 to 2004. With an average annual growth rate of 9 per cent in recent years, it is one of the fastest growing services sectors in UAE. Sea transport benefits from highly-developed ports. UAE's merchant fleet consists of 180 ships and ranked $31^{\text {st }}$ in the world in 2001 (WTO, 2006). The government of UAE owns Emirates airlines, which is world's fastest growing airline with an annual average growth rate of 20 per cent. The share of exports of this sector in trade of services was 4 per cent in 2004. However, the country is a net importer of transport services and its trade deficit in transport was estimated to be US\$0.5 billion in 2004 (Chart 10.4).

The UAE government is putting more and more emphasis on increasing revenues from the tourism sector. It has undertaken numerous initiatives in this regard, with the result that tourism is growing very fast - almost three times more than world tourism - and constituted 12 per cent of GDP in 2003. ${ }^{1}$ Dubai, the second largest state in terms of its economic size, has emerged as a major tourist destination in recent years. With over 270 hotels and 30 shopping malls, 5 million tourists visited Dubai and 16 million passengers used its airport in 2007.

Tourism exports for UAE account for 6 per cent of the country's total trade in services. UAE remained a net importer of travel services throughout the last decade. However, the trend may reverse considering the rapid growth of the sector (see Table 10.2). In 2002, Dubai was ranked as the fastest growing tourist destination by the World Tourism Organisation.

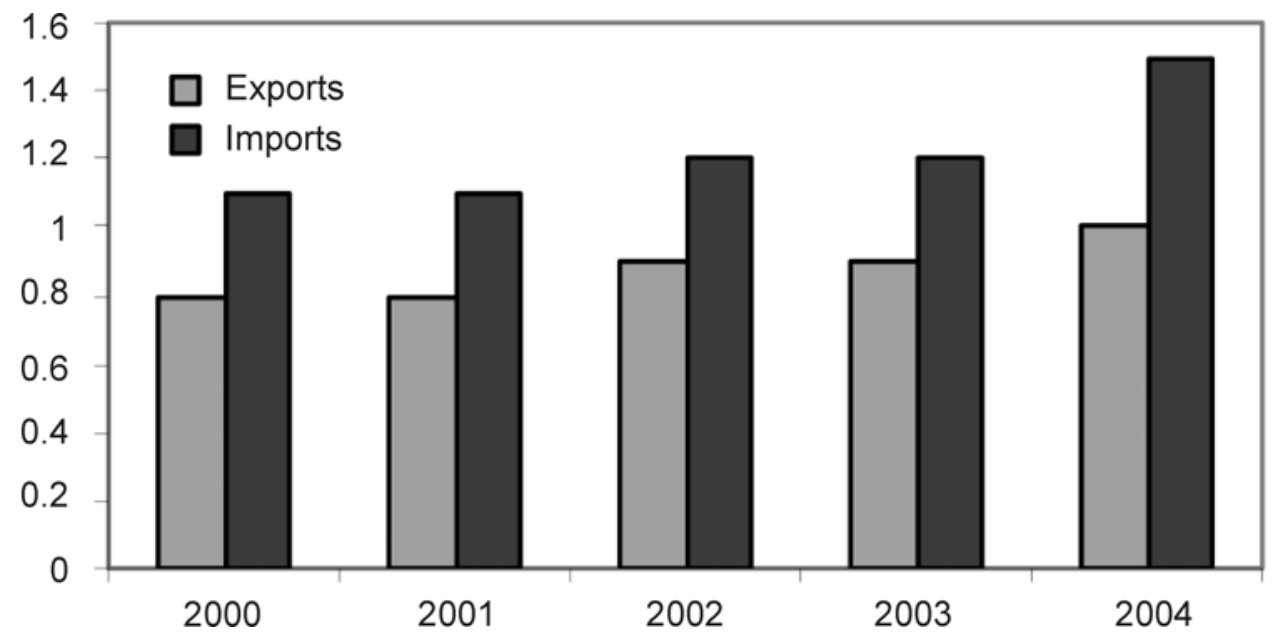

Chart 10.4: Trade in transport, storage and communications for UAE (US\$ million) Source: UNCTAD (2005) 
Table 10.2: Selected indicators of tourism for UAE

\begin{tabular}{lccccc}
\hline & \multicolumn{5}{c}{ Growth rate (\%) } \\
\hline & 1995 & 2000 & 2003 & $1995-2000$ & $2000-03$ \\
\hline Hotels (number) & & & & & \\
Dubai & 229 & 265 & 271 & 3.0 & 0.7 \\
Abu Dhabi & 39 & 49 & 52 & 4.7 & 2.0 \\
Other emirates & 29 & 39 & 43 & 6.1 & 3.3 \\
Hotel revenues (US\$ million) & & & & & \\
Dubai & 389.3 & 714.8 & $1,093.5$ & 12.9 & 15.2 \\
Abu Dhabi & 184.8 & 234.1 & 271.2 & 4.8 & 5.0 \\
Other emirates & 57.0 & 62.2 & 111.4 & 1.8 & 21.4 \\
\hline
\end{tabular}

\section{Supporting factors}

\section{Domestic capacity and skills}

The total adult literacy rate in UAE in 2005 was 76 per cent, while the gross tertiary enrolment ratio in 2002 was 23 per cent (13 per cent for males and 40 per cent for females). The United Nations Development Programme (UNDP) (2005) ranked UAE as $49^{\text {th }}$ out of 177 countries in terms of its human development indicators. However, despite its relatively strong position in terms of human development, the country lacks local skilled labour and most of the skilled workforce in the country comprises expatriates and foreigners. UAE has a relatively open labour market; hence lack of availability of foreign skilled workers is not a major impediment to private-sector development (more than 90 per cent of the total workforce in UAE is foreign).

The ICT infrastructure of UAE is well developed, especially in terms of access and affordability (Table 10.3). Telecommunications services have been modernised in recent years, with the result that the rate of mobile telephony coverage is 100 per cent. The number of fixed lines has been growing steadily; however, telephone density has fallen in recent years because of population growth exceeding that of telephone lines (WTO, 2006).

In terms of transport, infrastructure for all modes of transportation - by air, sea and road - is excellent in UAE. Roads connect all major cities of the country and are in good condition. Almost the entire road network $(4,000 \mathrm{kms})$ is paved. Sea transport benefits from the presence of 15 large commercial ports with a total capacity of over 70 million tonnes. Dubai's Jebel Ali Port is the world's largest manufactured port. There are six international airports in UAE, which serve as major connecting points for the region with the rest of the world. Dubai airport is ranked $16^{\text {th }}$ in the world in international passenger throughput and $17^{\text {th }}$ in cargo tonnage (WTO, 2006). The country also has various 'cargo villages' that offer world-class cargo, storage and re-export services. 
Table 10.3: ICT indicators for UAE (2005)

\begin{tabular}{lcc}
\hline & UAE & High-income group \\
\hline Access & & \\
Tel. main lines per 1,000 people & 273 & 503 \\
Mobile subscribers per 1,000 people & 1,000 & 835 \\
Population covered by mobile telephony (\%) & 100 & 99 \\
Internet users (per 1,000 people) & 308 & 527 \\
Personal computers (per 1,000 people) & 197 & 579 \\
Quality & & \\
International internet bandwidth (bits per person) & 923 & 4,537 \\
Affordability & & \\
Price basket for fixed line (US\$ per month, residential) & 17.4 & 27.6 \\
Price basket for mobile (US\$ per month) & 4.1 & 17.8 \\
Price basket for Internet (US\$ per month) & 13.1 & 19.9 \\
Price of call to United States (US\$ per 3 minutes) & 1.73 & 0.76 \\
\hline
\end{tabular}

Note: * value is for the year 2000

Source: World Bank (2006) Information and Communications for Development 2006: Global Trends and Policies. Washington DC: World Bank

\section{Policy and institutional framework}

The government of UAE has played a critical role in the private-sector development of the economy. Through infrastructure development, political stability, increased transparency, updating of laws and regulations according to international requirements, and streamlining administrative requirements, it has created a favourable business investment climate. This has attracted domestic and foreign investment in various services such as in oil and gas-field services, cargo and shipping, telecommunications and finance. UAE fares well in the World Bank's governance indicators, especially in comparison to the average of small states and the regional average. However, its performance lags behind that of the high-income group (Table 10.4).

Table 10.4: Governance indicators for UAE, 2005

\begin{tabular}{lccccc}
\hline & 2005 & $\begin{array}{c}\text { Average } \\
\text { 2000-05 }\end{array}$ & $\begin{array}{c}\text { High-income } \\
\text { group (2005) }\end{array}$ & $\begin{array}{c}\text { Middle East } \\
\text { E North } \\
\text { Africa (2005) }\end{array}$ & $\begin{array}{c}\text { Small states } \\
\text { (2005) }\end{array}$ \\
\hline Political stability & 0.61 & 0.79 & 0.81 & -0.51 & 0.40 \\
Government effectiveness & 0.55 & 0.76 & 1.27 & -0.21 & 0.25 \\
Regulatory quality & 0.44 & 0.74 & 1.23 & -0.28 & 0.27 \\
Rule of law & 0.58 & 0.92 & 1.26 & -0.04 & 0.32 \\
Control of corruption & 1.13 & 1.08 & 1.36 & -0.01 & 0.30 \\
\hline
\end{tabular}

Notes: Units of measures range from about -2.5 to 2.5 , with higher values corresponding to better governance outcomes

Source: World Bank (2006) 
The government has provided various incentives to foreign investment in the services sector. For example, creation of a free zone in Dubai provides incentives to foreign financial companies to enter the market, expand their businesses in the region, and benefit from the no taxation policy of the government.

The Central Bank of UAE (CBU) is the premier monetary institution that oversees the operations of most financial institutions in the economy. ${ }^{2}$ Insurance services are regulated by the Ministry of Economy and Planning. Trade policy is also formulated by the Ministry of Economy and Planning, with assistance from other relevant departments and trade bodies. Investment policy is implemented through a licensing scheme that requires all business to obtain a licence (WTO, 2006). Although, UAE has an investment-friendly climate, its regulatory and judicial frameworks continue to discriminate between locals and foreign investors and the latter cannot own businesses except in the free zones. This also holds for land ownership, albeit laws vary across the emirates. Recently Dubai allowed foreigners to own properties in three government-owned housing projects. Abu Dhabi also has a law, which permits leasing of properties in investment areas to foreigners for a limited duration.

In terms of transport, regulation of shipping services is carried out by the Ministry of Commerce (which oversees security, communications, seaworthiness and ensures quality control) and the port authorities of individual emirates (which oversee port handling services such as lifting, loading, discharging, storage and warehousing, and pilotage). Civil aviation is the responsibility of individual emirates; however, the General Civil Aviation Authority, which is a federal organisation, oversees activities related to civil aviation.

Telecommunications services are regulated by the Supreme Committee for the Supervision of the Telecommunications Sector, which is responsible for drafting and implementing the telecoms policy as well as for issuing licences. In 2004, the Telecommunication Regulatory Authority was also set up to improve ICT infrastructure and services. In the tourism sector, individual emirates are responsible for formulating and implementing policies.

\section{External conditions}

UAE became one of the original members of the WTO in 1996. Alongside this multilateral initiative, it has signed bilateral free trade agreements (FTAs) with Syria, Iraq, Jordan, Lebanon and Morocco. The country is also negotiating FTAs with Australia, the USA, EU and China. Since it is a member of the Arab Gulf Cooperation Council, it is required to harmonize its trade legislation with that of other member states (WTO, 2006).

UAE committed to GATS in certain areas, although with certain limitations. For example, in the financial services sector restrictions relate to discrimination in investments and shareholding between nationals and non-nationals. The country made no commitments in insurance services; cross-border supply of insurance services cannot 
be carried out by firms located abroad and foreign ownership restrictions apply. Similarly, the following are limited to UAE nationals: real estate services; rental/leasing services related to road transportation; services related to agriculture, hunting and forestry, and fishing; placement, investigation and security services; and passenger and freight road transport (WTO, 2006).

For various professional and business services such as auditing, accounting, taxation, architectural services, engineering, urban planning and veterinary services, UAE has bound commitments in modes 1 to 3 . In the tourism sector, provision of hotel and restaurant services is bound, without limitations through modes 1 and 2. However, in mode 3 (commercial presence) a restriction on foreign ownership (which can be up to a maximum of 49 per cent) exists. In the construction services sector, UAE has not made any commitment under GATS; however, it is not a protected sector and numerous foreign contractors are working in the country. Nor has the country made any commitments in the transport and telecommunications sectors. Here, large state-owned enterprises are the major players in the market and majority foreign ownership is prohibited.

\section{Institutional support}

In the UAE, each emirate has a chamber of commerce and industry. The Federation of UAE Chambers of Commerce and Industry is the umbrella organisation, which consists of the seven emirates chambers of commerce as its members. The Abu Dhabi Chamber of Commerce and Industry (ADCCI), which was set up in 1969, has grown to become the largest Chamber of Commerce and Industry in the Arab Gulf Cooperation Council (AGCC). It has over 55,000 members and represents the manufacturing and services activities of the private sector in national and international forums. ADCCI also provides technical and financial support to small and medium enterprises, promotes UAE's private sector in international markets, and provides regulatory, policy and commercial information to domestic and foreign producers and investors.

In addition, government investment development offices/authorities exist in all emirates to identify new investment opportunities and facilitate investment processes to create a business-friendly climate and attract investors.

\section{Conclusions}

The rapid development of the United Arab Emirates has been made possible by the pro-active attitude of the government and co-operation between the public and private sectors. An example is the setting up of a one-stop-shop at Abu Dhabi Municipality through collaboration between different government agencies and the ADCCI to facilitate the issuance of trade licences and make the procedure simpler and quicker. The public sector took the lead and provided the right incentives for industry to develop in the country. A diverse range of initiatives have been undertaken to make the most of the country's endowments and promote growth, trade and investment. 
One of the most significant steps in this regard was the development of airport and seaport facilities during the 1960s and 1970s, which led UAE to become a leading transhipment and re-export centre. The government developed transportation infrastructure and established efficient state-owned enterprises. In both shipping and air transport services, most companies including the largest and most-profitable ones are government owned.

Capitalising on Dubai's strategic location and good infrastructure, the UAE government initiated an 'open skies policy', which has made the country, especially Dubai, the regional hub of trade and commercial activities (see Box 10.1).

Box 10.1: Dubai's Open Skies Policy

Dubai operates an 'open skies' policy by allowing over 100 airlines other than its national carrier, Emirates airlines, to operate from the airport of Dubai and utilise its airport and refuelling services. This has made UAE a land-bridge between continents and has increased Dubai's interconnection regionally as well as globally, making it a hub for tourism traffic. In 2004 alone, 16 million passengers passed through Dubai airport and the number is expected to increase four-fold by the end of the decade.

The open skies policy has caused tremendous growth in Dubai's civil aviation sector and has benefited the overall development of the economy. It has boosted the demand for Dubai's goods and services, causing a boom in the travel and tourism industry. The competitive environment has also had a beneficial effect on its own airline, and has enhanced its efficiency and profitability. Dubai is now taking the lead in the drive of liberalising civil aviation services in the entire Gulf region.

Other important initiatives include massive public investments in parks, sports facilities, international conference centres, the organisation of high-profile sporting and shopping events and so on to develop the tourism industry. Dubai's government has been leading the drive to develop tourism (see Box 10.2 for some projects started in Dubai).

To facilitate foreign investment, a simple but very useful initiative was the initiation of a 24-hour telephone and fax hotline at the Dubai Naturalization and Residency Department, which provides information regarding different types of visa, various documents required for opening a company file at the department, court appointments, changing visas and departure certificates. Another recent and major step to make Dubai the regional financial centre and to attract foreign investment is the creation of the Dubai International Financial Center (DIFC) (see Box 10.3).

With the co-operation of the public sector, the private sector is also taking initiatives for further development. An example is the setting up of a one-stop-shop at Abu Dhabi Municipality, the result of a collaboration between different government agencies and 
Box 10.2: Selected projects in Dubai

In 2004, Dubai Healthcare City, a newly created free zone, began providing specialised medical and healthcare services with the help of partners and investors from regional and international clinics. The project targets customers from the Gulf Cooperation Council (GCC), the Indian subcontinent, East Africa and Central Asia. A turnover of US $\$ 1$ billion was expected in 2005.

The US\$3 billion Palm Island project for the construction of two artificial, palm-shaped islands off Dubai's coast is a by-product of the Jebel Ali harbour expansion. Each island will have around $60 \mathrm{~km}$ of coastline. The islands will house residential homes and hotels, as well as entertainment and retail outlets. Infrastructure work on the first island was completed in 2004. In addition, there are plans to build a similar group of 200 artificial islands in the shape of the world map.

With a total investment of almost US\$6 billion and an assigned space of 4 billion square feet (372 million square metres), Dubailand is one of the world's largest self-contained tourism projects, offering leisure, sport, retail and entertainment attractions. The launch phase, covering initial infrastructure like road works and utility provision, was intended to extend from 2004 to 2006. The main construction phase will be completed by 2010. Financing is mostly from the private sector, both domestic and foreign.

Other projects include the construction of the world's first luxury underwater hotel, as well as the only indoor skiing centre in the Gulf region, Dubai Snow World. In 2004, Dubai Holding was established as a Dubai government-owned organisation charged with running some of the emirate's major ventures. They include Dubailand, Dubai Internet City and Jumeirah Beach Residence.

Source: WTO (2006)

Box 10.3: Dubai International Financial Center (DIFC)

DIFC was created in 2004 as a financial hub for the Middle Eastern region by the government. It aims to develop the financial services sector of UAE and attract investment for growth, infrastructure and overall economic development of the country and the wider region. DIFC focuses on banking services, capital markets, asset management and fund registration, reinsurance, Islamic finance, and back office operations.

DIFC is a project with immense potential. It has already attracted global firms and is expected to further boost employment, investment, and growth. It consists of a capital market which is a financial free zone. Financial institutions benefit from a zero income tax rate, 100 percent foreign ownership, dollar denominated environment, and no restrictions on foreign exchange or capital outflow. The Dubai International Financial Exchange was set up in 2005 as a subsidiary of DIFC.

ADCCI to facilitate the issuance of trade licences and make the whole procedure faster and easier.

UAE is also promoting trade in education services. A notable example in this regard is the investment in Dubai Knowledge Village (see Box 10.4). 
Box 10.4: Dubai and promoting trade in education services

To promote secondary and tertiary educational services, UAE has liberalised its economy to educational institutions. At the time of writing there were 40 accredited universities, colleges and academies in addition to three federal higher education institutions. There are least 16 institutions in free zones, such as the Dubai Knowledge Village (DKV). The UAE's open door policy to new universities allows institutions to determine the programmes that they offer, based on student demand and willingness to pay.

The DKV emerged as recently as 2003 as part of the free zone. The establishment of a free zone required a lot of investment, but it has had various benefits including significant job creation. During 2001-2004, the free zone created 1,800 companies, 21,000 knowledge workers and 15 universities, with US $\$ 2$ billion of investment. The DKV includes foreign branches of universities, colleges or schools providing accredited academic programmes and degrees. The Village offers a one-stop-shop for all educational and business needs: enabling physical infrastructure and high-performing technology infrastructure, networking opportunities, access to a large pool of knowledge workers, simplified laws and regulations, student visas made easy, 100 per cent foreign ownership and a tax-free environment.

\section{Notes}

1. Source: WTO (2006).

2. An exception to this is the Dubai International Financial Centre, which was established by the government to create a regional capital market. It is regulated by the Dubai Financial Services Authority. 
